\title{
Risk Factors for Postpartum Thyroid Dysfunction in Euthyroid Women Prior to Pregnancy
}

\author{
Boyan I. Nonchev ${ }^{1,2}$,Antoaneta V. Argatska ${ }^{1,2}$, Blagovest K. Pehlivanov ${ }^{3}$, Maria M. Orbetzova ${ }^{1,2}$ \\ 1 Section of Endocrinology, Department of Internal Diseases, Faculty of Medicine, Medical University of Plovdiv, Plovdiv, Bulgaria \\ ${ }^{2}$ Clinic of Endocrinology and Metabolic Diseases, St. George University Hospital, Plovdiv, Bulgaria \\ ${ }^{3}$ Department of Midwifery cares, Faculty of Public Health, Medical University of Plovdiv, Plovdiv, Bulgaria
}

\section{Correspondence:}

Antoaneta V. Argatska, Section of Endocrinology, Department of Internal Diseases, Faculty of Medicine, Medical University of Plovdiv,

15a Vassil Aprilov Blvd., 4002 Plovdiv, Bulgaria

E-mail: lakalma@abv.bg

Tel: +359898411049

Received: 25 Nov 2015

Accepted: 03 Nov 2016

Published Online: 06 March 2017

Published: 27 June 2017

Key words: postpartum period, thyroid dysfunction, risk factors, thyroid autoimmunity

Citation: Nonchev BI, Argatska AV, Pehlivanov BK, Orbetzova MM. Risk factors for postpartum thyroid dysfunction in euthyroid women prior to pregnancy.

Folia Medica 2017;59(2):190-196. doi: 10.1515/folmed-2017-0027
Background: Thyroid dysfunction is common during the postpartum and the predisposing factors for its development are considered specific for the population studied. The aim of this study was to evaluate the risk factors for the occurrence of postpartum thyroid dysfunction (PPTD) in euthyroid women prior to pregnancy.

Materials and methods: Forty-five women with PPTD and 55 age-matched euthyroid postpartum women from Plovdiv, Bulgaria were included in the study. TSH, FT4, FT3, TPOAb, TgAb, TRAb were measured and ultrasound evaluation of the thyroid was performed in the first trimester of pregnancy and during the postpartum.

Results: The study found higher risk of developing PPTD in women with family history of thyroid disease (OR 4.42; $95 \% \mathrm{Cl} 1.87,10.43$ ), smokers (OR 4.01; 95\% $\mathrm{Cl} 1.72,9.35)$, personal history of autoimmune thyroid disease $(\mathrm{OR} 5.37 ; 95 \% \mathrm{Cl}$ 1.15,28.53), positive TPOAb (OR 18.12; $95 \% \mathrm{Cl} 4.93,66.65)$ and thyroid US hypoechogenicity during early pregnancy $(\mathrm{OR} 6.39 ; 95 \% \mathrm{Cl} 2.53,16.12)$ and those who needed levothyroxine during pregnancy (OR 3.69; 95\% Cl 1.28,10.61). BMI before pregnancy was significantly lower in women with PPTD than in euthyroid postpartum women $(22.80 \pm 0.55$ vs $26.25 \pm 0.97, p=0.013)$. The multivariate logistic regression analysis identified as most important independent risk factors for PPTD occurrence the TPOAb positivity during early pregnancy, family history of thyroid disease, smoking and lower BMI before pregnancy.

Conclusion: Our data suggest that in the population studied several factors are associated with an increased risk of PPTD and screening for thyroid disorders among those women can be beneficial.

\section{BACKGROUND}

Postpartum thyroiditis (PPT) presents either with thyrotoxicosis or hypothyroidism within the first year after delivery with a variable prevalence in different geographic regions. ${ }^{1,2}$ Many factors known to affect thyroid function have been studied and the evidence regarding their predictive value is abundant, but still remains inconclusive. At present, universal screening for thyroid dysfunction either during or after pregnancy is not generally recommended., ${ }^{1,3}$ Therefore further studies are needed to elucidate the risk factors for the development of postpartum thyroid dysfunction (PPTD) and to contribute to the promotion of appropriate cost-effective screening programs suited for the region and population studied.

\section{AIM}

The aim of this study was to evaluate the risk factors for the occurrence of thyroid dysfunction during the postpartum period in euthyroid women prior to pregnancy.

\section{MATERIALS AND METHODS}

One hundred and forty-one Caucasian first-trimester pregnant women from Plovdiv, Bulgaria were referred to the Clinic of Endocrinology at St. George University Hospital in Plovdiv over a 3-year period (2012-2014) for thyroid function screening. They were followed during the first year after delivery for assessment of thyroid function. Thirty-one women who had been taking either levothyroxine or antithy- 
roid drugs for the past 12 months before pregnancy were excluded from the study as well as 8 women who did not return for follow-up after delivery. Two women who presented with high levels of thyroid hormones along with unsuppressed TSH were also excluded and later were diagnosed with thyroid hormone resistance syndrome. The study included the rest 100 women of whom 45 developed PPTD and 55 euthyroid postpartum euthyroid women as a control group. All women were in euthyroid state before pregnancy without any thyroid treatment and had no concomitant diseases or conditions that could interfere with the thyroid function tests.

The study complied with the recommendations of the Declaration of Helsinki and was approved by the local Ethic Committee at the Medical University of Plovdiv. The general purpose of the study and its design were explained to the patients and all participants signed a written informed consent form.

Serum levels of thyroid stimulating hormone (TSH), free triiodothyronine (FT3), free thyroxine (FT4), thyroid peroxidase antibodies (TPOAb) and thyroglobulin antibodies ( $\mathrm{TgAb}$ ) were measured using chemiluminescence immunoassay (Beckman Coulter, Access2). Measurement units and reference ranges were as follows: TSH, $0.34-5.60$ $\mathrm{mIU} / \mathrm{l}$; FT4, 7.86 - $14.40 \mathrm{pmol} / \mathrm{l}$; FT3, $3.60-6.00$ $\mathrm{pmol} / \mathrm{l}$. TPOAb levels were considered positive if greater than $9 \mathrm{IU} / \mathrm{ml}$ (normal range $0-9 \mathrm{IU} / \mathrm{ml}$ ) and $\mathrm{TgAb}$ - greater than $4 \mathrm{IU} / \mathrm{ml}$ (normal range $0-4 \mathrm{IU} / \mathrm{ml})$.

Ultrasound examination was performed by an experienced clinician both during pregnancy and during the puerperal period using 5-13 $\mathrm{MHz}$ linear transducer (Siemens Acuson U300). Thyroid volume was calculated for each lobe individually using Brunn's formula: V $(\mathrm{ml})=0.479 \mathrm{x}$ length $\mathrm{x}$ depth $\mathrm{x}$ width. ${ }^{4}$ Thyroid parenchyma hypoechogenicity was determined by a 4 -grade scale compared to the echoic pattern of the prethyroid muscles. For the purpose of the study thyroid echogenicity was classified into two groups: normoechoic (grade 0) and hypoechoic (grades 1, 2 and 3).

Clinical examination, thyroid function tests, serum thyroid auto-antibody measurement and ultrasound evaluation of the thyroid were performed between 6 and 14 week of gestation and between 2 and 7 months after delivery. Personal and medical information recorded included height and weight before pregnancy, family history of thyroid disease, tobacco use, personal history of autoimmune thyroid disease (autoimmune thyroiditis, Grave's disease or previous episode of PPT), number of pregnancies prior to current gestation, history of infertility and miscarriages, presence of concomitant autoimmune disorders, blood group and rhesus factor. Levothyroxine (LT4) was initiated in women with TSH levels above trimester-specific ranges at the initial visit ( $\mathrm{TSH} \geq 2.5 \mathrm{mIU} / 1$ during the first trimester). ${ }^{1}$ After parturition women on supplementation therapy were advised to discontinue treatment. Clinical examination was performed and information regarding the course of pregnancy was obtained.

Postpartum women were considered euthyroid when TSH was within $0.34-4.2 \mathrm{mIU} / 1$ after delivery; thyrotoxicosis was defined as suppressed levels of TSH $(<0.34 \mathrm{mIU} / \mathrm{l})$ and hypothyroidism - elevated TSH $(>4.20 \mathrm{mIU} / \mathrm{l})$ during the postpartum.

The statistical package for the social sciences (SPSS, Inc., Chicago, IL) version 17.0 was used to analyze the collected data. Descriptive data were presented as mean \pm standard error of the mean and/or percentage. Parametric (Student's t-test) and non-parametric (Mann-Whitney U-test) were applied. Categorical variables were analysed using Fisher's exact test. Univariate and multivariate logistic regression were used to identify factors associated with the risk for PPTD development. $\mathrm{P}<0.05$ was considered significant.

\section{RESULTS}

PPTD presenting with thyrotoxicosis occurred in 26 $(57.8 \%)$ of the women studied $4.77 \pm 0.33$ months postpartum and the other $19(42.2 \%)$ were afflicted with hypothyroidism $6.26 \pm 0.46$ months after delivery. Characteristics of the studied women are presented in Table 1.

At follow-up at the end of the postpartum period thyroid function assessment showed that $31.1 \%$ of the women had restored their euthyroid state (17.8\% had experienced transient thyrotoxicosis and $13.3 \%$ - transient hypothyroidism). Biphasic course of the disease with thyrotoxic phase followed by hypothyroidism was found in $28.9 \%$ of the women with PPTD. Persistent thyrotoxicosis was found in $11.1 \%$, and persistent hypothyroidism - in $28.9 \%$ of the patients.

$33(73.3 \%)$ of the women experienced overt form of thyroid dysfunction while in the other $12(26.7 \%)$ thyroid functional abnormalities were present without clinically overt signs and symptoms and the diagnosis was made on the basis of hormonal results. Thyroid antibodies were present in the majority of women $(80 \%)$ whereas in $9(20 \%)$ 
Table 1. Characteristics of the studied women

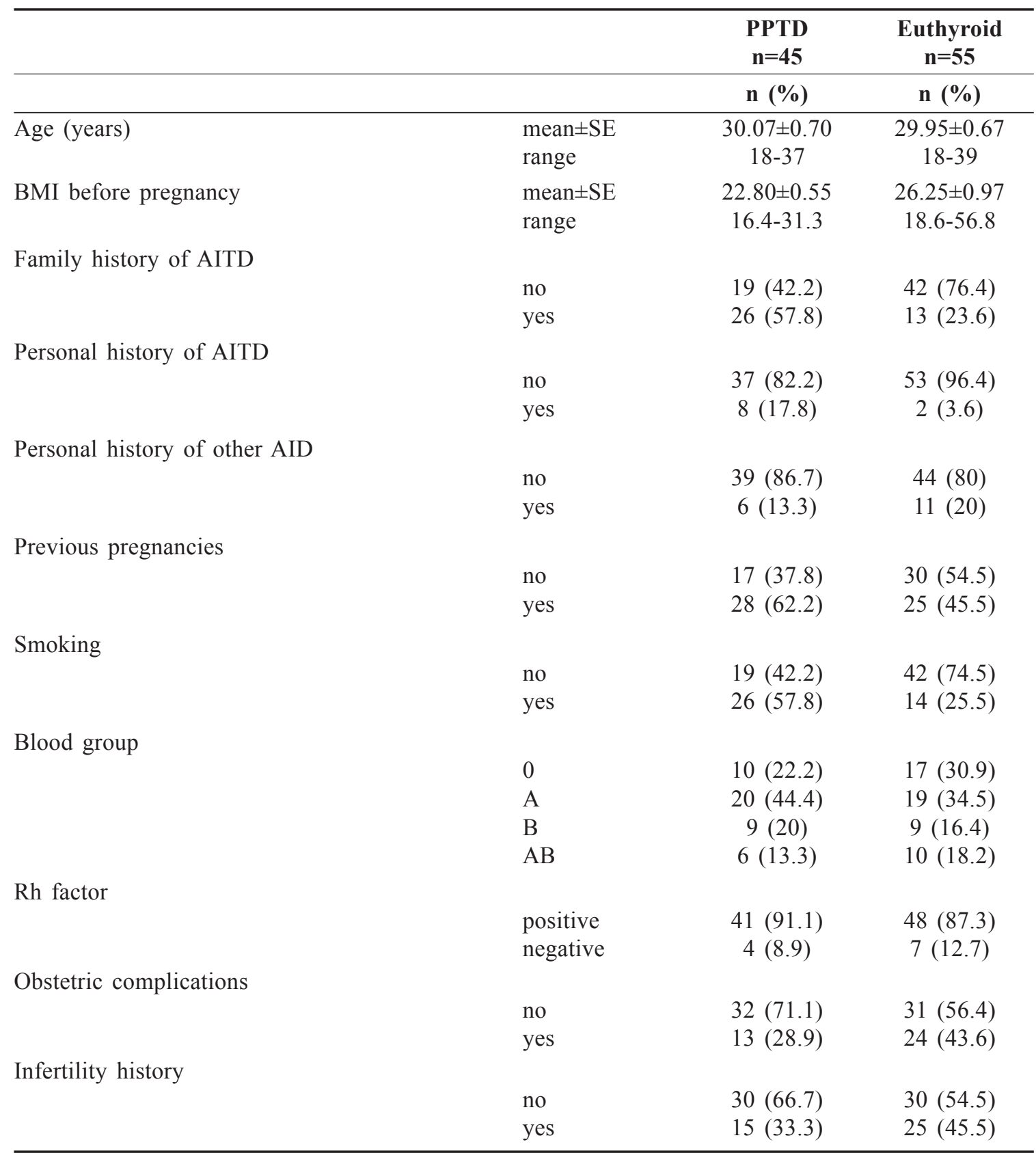

AITD - autoimmune thyroid disease

AID - autoimmune disease

of the patients with PPTD both TPOAb and TgAb titers were negative. US examination revealed hypoechoic pattern of thyroid parenchyma in $95.6 \%$ of the patients with hormonal abnormalities and only in $4.4 \%$ of the women PPTD developed without morphological changes.

Univariate analysis estimated a significantly higher risk for PPTD among women who were positive for TPOAb, had hypoechoid US pattern of the thyroid during pregnancy, women with family and personal history of autoimmune thyroid disease, smokers and women who were on levothyroxine treatment during pregnancy. The analysis also found that women who developed PPTD had significantly lower BMI before pregnancy compared to euthyroid postpartum women (Table 2). The sensitivity and specificity of the predictive model were $75.56 \%$ and $87.27 \%$, respectively.

None of the following parameters was related to the development of PPTD: age ( $\mathrm{p}=0.901)$; parity $(\mathrm{p}=0.110)$; history of infertility, including spontaneous abortion $(\mathrm{p}=0.305)$; history of other autoim- 
Table 2. Factors associated with increased risk of developing PPTD

\begin{tabular}{lccccc}
\hline & & Euthyroid & PPTD & OR [95\%CI] & P \\
\hline History of AITD & yes & 2 & 8 & 5.37 & 0.040 \\
& no & 53 & 37 & {$[1.15,28.53]$} & \\
Family history of AITD & yes & 13 & 26 & 4.42 & 0.001 \\
& no & 42 & 19 & {$[1.87,10.43]$} & \\
Smoking & yes & 14 & 26 & 4.01 & 0.002 \\
& no & 41 & 19 & {$[1.72,9.35]$} & \\
TPOAb in the 1st trimester & positive & 3 & 23 & 18.12 & 0.000 \\
& negative & 52 & 22 & {$[4.93,66.65]$} & \\
Thyroid US in the 1st trimester & normal & 46 & 20 & 6.39 & 0.000 \\
& hypoechoic & 9 & 25 & {$[2.53,16.12]$} & \\
LT4 during pregnancy & yes & 6 & 14 & 3.69 & 0.022 \\
& no & 49 & 31 & {$[1.28,10.61]$} & \\
BMI before pregnancy & & & & \\
Mann-Whitney U-test & mean \pm SE & $26.25 \pm 0.97$ & $22.80 \pm 0.55$ & & 0.013 \\
\hline
\end{tabular}

Table 3. Independent predictors of PPTD

\begin{tabular}{lccccc}
\hline \multicolumn{1}{c}{ Factors } & $\begin{array}{c}\text { Standardized } \\
\text { coefficient }\end{array}$ & $\begin{array}{c}\text { Standard } \\
\text { error }\end{array}$ & Exp. (B) & Sig. & $\mathbf{9 5 \% C I ~}$ \\
\hline TPOAb+ & 2.202 & 0894 & 9.047 & 0.014 & $1.568,52.203$ \\
Family history of AITD & 1.281 & 0.559 & 3.600 & 0.022 & $1.203,10.771$ \\
Smoking & 1.281 & 0.559 & 3.600 & 0.022 & $1.158,11.200$ \\
BMI & -0.151 & 0.067 & 0.860 & 0.024 & $0.754,0.981$ \\
\hline
\end{tabular}

mune diseases $(p=0.432)$; blood group $(p=0.602)$ and rhesus factor $(\mathrm{p}=0.750)$; TSH $(\mathrm{p}=0.081)$, thyroid volume $(p=0.055)$ and positive titers of $\mathrm{TgAb}$ in the first trimester of pregnancy $(\mathrm{p}=0.222)$.

A multifactorial analysis was performed using the variables defined as risk factors for developing PPTD. The logistic regression analysis selected as most important independent risk factors for PPTD the TPOAb positivity in early pregnancy, family history of thyroid disease, smoking and BMI (Table 3).

\section{DISCUSSION}

PPTD is a relatively common finding during the first year after delivery in a significant part of the affected women. The estimated high prevalence of the disease, the considerable morbidity related to it and its occurrence in subsequent pregnancies has prompted a discussion about early identification of women at increased risk of thyroid disease in order to ensure proper treatment and to prevent further complications.

At present TPOAb is generally recommended as an useful prognostic factor for development of PPTD $^{5-9}$ and particularly first-trimester TPOAb titers showing positive predictive value in assessing the risk of postpartum thyroid disorders. ${ }^{10}$ In our study the presence of TPOAb in early pregnancy proved to be a significant prognostic factor for the occurrence of PPTD. However, PPTD has been observed in a small percentage of women in the absence of thyroid antibodies. ${ }^{11,12}$ A small but considerable part of the studied women developed thyroid dys- 
function without laboratory signs of autoimmune thyroiditis suggesting that in populations where postpartum thyroid disorders occur in the absence of thyroid antibodies the value of this parameter as a screening marker may be questionable.

Some authors confirm that thyroid hypoechogenicity predates the hormonal changes in PPTD but did not prove to be a reliable prognostic factor for its development. ${ }^{13}$ Others suggest that structural and echogenic changes might be of predictive value for the development of PPTD ${ }^{14}$ especially when TPOAb are borderline during pregnancy. ${ }^{15}$ Furthermore, TPOAb positivity in pregnant women is not invariably associated with prominent autoimmune pattern on thyroid US. ${ }^{16}$ Thus, thyroid US changes in early pregnancy may be considered an independent risk factor for development of postpartum thyroid disorders.

Women with personal history of thyroid disorders are at a higher risk of experiencing an episode of PPTD during the postpartum period. ${ }^{17,18}$ Consequently, a history of autoimmune thyroid disorder particularly Hashimoto thyroiditis, Graves' disease or previous PPT is a predisposing factor leading to a higher risk of developing PPTD (56.1-68\%; 44\% and $70 \%$ respectively). ${ }^{19-22}$ In accordance with this data, we also found an increased incidence of PPTD among women with AITD antedating pregnancy.

PPTD occurs more commonly among women with family history of thyroid disease. ${ }^{1,3,18}$ The results of our study confirm that having a first- or second degree relative with AITD is associated with a significant risk for PPTD. Although some authors found no significant correlation between the occurrence of PPTD and family history of thyroid disease $^{23}$, a positive history of thyroid disease in the family is widely considered a risk factor for its development.

Smoking is associated with an increased risk of developing Hashimoto thyroiditis as well as postpartum thyroiditis. ${ }^{24}$ In our series women who had ever smoked were more likely to experience an episode of postpartum thyroid dysfunction than women who were non-smokers. This finding is consistent with the report of Kuijpens et al. that smoking regardless of the duration and intensity was an independent risk factor for the occurrence of PPT (OR 3.1). ${ }^{25}$

Few studies concerning the possible impact of BMI as a risk factor for thyroid dysfunction during the postpartum period are currently available. In a series of 157 women Díaz et al. estimated a higher risk for PPTD in women with minor BMI before pregnancy. ${ }^{26}$ Analysis of our data support this finding as PPTD was more prevalent in women with a lower BMI before pregnancy compared to the postpartum euthyroid women.

In our series, women who were treated with levothyroxine during pregnancy were more likely to develop PPTD. Taking into account the results of the initial thyroid tests, replacement therapy was prescribed to 20 of the patients studied and treatment was discontinued following parturition. PPTD was observed in $14(70 \%)$ of that group of patients indicating that the reduced thyroid functional capacity during pregnancy may progress to further deterioration of thyroid function after delivery.

It has been suggested that with the increasing number of pregnancies the incidence of TPOAb positivity and the risk of PPTD rise ${ }^{27}$, but we did not find any differences in the prevalence of PPTD between primiparous and multiparous women. The data on the relation between PPTD and other autoimmune disorders apart from thyroid pathology indicate that PPTD occurs more commonly in patients with autoimmune diseases than in the general population, especially patients with type 1 diabetes mellitus ${ }^{28,29}$ or systemic lupus. ${ }^{30}$ In our series, 14 of the 17 women with underlying autoimmune disease had type $1 \mathrm{DM}$, but the risk of PPTD was not associated with the presence of this disorders.

Current guidelines recommend that pregnant women with infertility history, including recurrent miscarriages be screened for thyroid abnormalities due to the higher risk of obstetric complications and postpartum thyroid dysfunction. ${ }^{1,3,8}$ The results of our study did not establish either a greater frequency of PPTD or a higher prevalence of TPOAb in women with history of spontaneous abortion and in vitro fertilization. Evidence concerning the possible impact of blood group on the risk of developing thyroid dysfunction is scarce and unlike Díaz who found an increased frequency of PPT in Rh-negative women ${ }^{26}$ we did not prove association between blood group or rhesus factor and the risk for PPTD.

\section{CONCLUSION}

Postpartum thyroid dysfunction is a common disorder and is often characterized by significant fluctuations of thyroid hormones. The results of this study justify a thorough evaluation and close follow-up of thyroid function after delivery in women with 
positive TPOAb titers and US hypoechogenicity in early pregnancy, family and personal history of autoimmune thyroid disease, smoking, lower BMI and those taking levothyroxine during pregnancy.

\section{REFERENCES}

1. Stagnaro-Green A, Abalovich M, Alexander E, et al. Guidelines of the American Thyroid Association for the diagnosis and management of thyroid disease during pregnancy and postpartum. Thyroid 2011;21(10):1081-25.

2. Nicholson WK, Robinson KA, Smallridge RC, et al. Prevalence of postpartum thyroiditis: a quantitative review. Thyroid 2006;16:573-82.

3. De Groot L, Abalovich M, Alexander EK, et al. Management of thyroid dysfunction during pregnancy and postpartum: An Endocrine Society Clinical Practice Guideline. J Clin Endocrinol Metab 2012;97(8):2543-65.

4. Brunn J, Block U, Ruf G, et al. Volumetrie der schilddruse mittels Real-time-Sonographie. Dtsch Med Wochenschr. 1981;106(41):1338-40.

5. Muller AF, Drexhage HA, Berghout A. Postpartum thyroiditis and autoimmune thyroiditis in women of childbearing age: recent insights and consequences for antenatal and postnatal care. Endocr Rev 2001;22:605-30.

6. Adlan MA, Premawardhana LD. Thyroid peroxidase antibody and screening for postpartum thyroid dysfunction. J Thyroid Res 2011;2011:745135.

7. Vaidya B, Anthony S, Bilous M, et al. Brief report: detection of thyroid dysfunction in early pregnancy: universal screening or targeted high-risk case finding? J Clin Endocrinol Metab 2007;92(1):203-7.

8. Smallridge RC. Postpartum thyroid disease: a model of immunological dysfunction. Clin Appl Immunol Rev 2000;1:89-103.

9. Premawardhana LD, Parkes AB, John R, et al. Thyroid peroxidase antibodies in early pregnancy: utility for prediction of postpartum thyroid dysfunction and implications for screening. Thyroid 2004;14(8):610-5.

10.Lazarus JH, Premawardhana LD. Screening for thyroid disease in pregnancy. J Clin Pathol 2005;58(5):449-52.

11. Stuckey BGA, Kent GN, Ward LC, et al. Postpartum thyroid dysfunction and the long-term risk of hypothyroidism: results from a 12-year follow-up study of women with and without postpartum thyroid dysfunction. Clinical Endocrinology 2010;73(3):389-95.

12. Stagnaro-Green A, Schwarz A, Gismondi R, et al. High rate of persistent hypothyroidism in a largescale prospective study of postpartum thyroiditis in Southern Italy. J of Clin Endocrinol and Metab 2011;83(6):652-7.

13. Adams H, Jones MC, Othman S, et al. The sonographic appearances in postpartum thyroiditis. Clin Radiol 1992;45(5):311-5.

14. Pedersen OM, Aardal NP, Larssen TB, et al. The value of ultrasonography in predicting autoimmune thyroid disease. Thyroid 2000;10:251-9.

15.Lazarus JH, Mestman JH. Thyroid disorders during pregnancy and postpartum. In: Braverman LE, Cooper DS. Werner \& Ingbar's The Thyroid A Fundamental And Clinical Text. Philadelphia, USA: Wolters Kluwer I Lippincott Williams \& Wilkins; 2012:815-35.

16. Jiskra J, Bartáková J, Holinka Š, et al. Low concordance between positive antibodies to thyroperoxidase and thyroid ultrasound autoimmune pattern in pregnant women. Endocr J 2011;58(10):849-59.

17. Lazarus JH, Premawardhana LD. Postpartum thyroiditis. In: Weetman AP. Contemporary Endocrinology: Autoimmune diseases in endocrinology. Totowa, New Jersey: Humana Press; 2008:177-92.

18.Lazarus JH. Postpartum thyroid disease. In: The thyroid and reproduction - Merck European Thyroid Symposium. Georg Thieme Verlag 2009;105-13.

19. Caixas A, Albareda M, Garcia-Patterson A, et al. Postpartum thyroiditis in women with hypothyroidism antedating pregnancy? J Clin Endocrinol Metab 1999;84:4000-5.

20. Sergi M, Tomlinson G, Feig DS. Changes suggestive of postpartum thyroiditis in women with established hypothyroidism: incidence and predictors. Clin Endocrinol (Oxf) 2015;83(3):389-93.

21. Tagami T, Hagiwara H, Kimura T, et al. The incidence of gestational hyperthyroidism and postpartum thyroiditis in treated patients with Graves' disease. Thyroid 2007; 17:767-72.

22. Lazarus JH, Ammari F, Oretti R, et al. Clinical aspects of recurrent postpartum thyroiditis. Br J Gen Pract 1997;47:305-8.

23. Shahbazian HB, Sarvghadi F, Azizi F. Prevalence and characteristics of postpartum thyroid dysfunction in Tehran. Eur J Endocrinol 2001;Oct;145(4):397-401.

24. Vestergaard P. Smoking and thyroid disorders--a meta-analysis. Eur J Endocrinol. 2002;146(2):153-61.

25. Kuijpens JL, Pop VJ, Vader HL, et al. Prediction of postpartum thyroid dysfunction: can it be improved? Eur J Endocrinol 1998;139:36-43.

26. Jaén Díaz JI, López De Castro F, Cordero García B, et al. Incidence of postpartum thyroiditis and study of possible associated factors. Med Clin (Barc). 2009;132(15):569-73.

27. Greer LG, Casey BM, Halvorson LM, et al. Antithyroid antibodies and parity: further evidence for microchimerism in autoimmune thyroid disease. Am 
J Obstet Gynecol 2011;205:471.e1-4.

28. Alvarez-Marfany M, Roman SH, Drexler AJ, et al. Long-term prospective study of postpartum thyroid dysfunction in women with insulin dependent diabetes mellitus. J Clin Endocrinol Metab 1994;79:10-6. 29. Gerstein HC. Incidence of postpartum thyroid dys- function in patients with type I diabetes mellitus. Ann Intern Med 1993;118:419-23.

30. Stagnaro-Green A, Akhter E, Yim C, et al. Thyroid disease in pregnant women with systemic lupus erythematosus: increased preterm delivery. Lupus 2011;20(7):690-9.

\title{
Факторы риска появления послеродовой дисфункции щитовидной железы у женщин с эутиреоидным состоянием до наступления бе- ременности
}

\author{
Боян И. Нончев ${ }^{1,2}$ Антоанета В. Аргатска ${ }^{1,2}$ Благовест К. Пехливанов ${ }^{3}$, Мария М. Орбецова ${ }^{1,2}$ \\ ${ }^{1}$ Секция „Эндокринология", Кафедра внутренних болезней, Факультет медицины, Медицинский университет - Пловдив, \\ Пловдив, Болгария. \\ 2 Клиника эндокринологии и метаболических заболеваний, Университетская больница „Св. Георгий”, Пловдив, Болгария \\ ${ }^{3}$ Кафедра акушерства и гинекологии, Факультет медицины, Медицинский университет - Пловдив, Пловдив, Болгария
}

\begin{abstract}
Адрес для корреспонденции: Антоанета В. Аргатска, Секция „Эндокринология", Кафедра внутренних болезней, Факультет медицины, Медицинский университет Пловдив, бул. „Васил Априлов" 15A, 4002 Пловдив, Болгария

E-mail: lakalma@abv.bg

тел: +359898411049
\end{abstract}

Дата получения: 25 ноября 2015

Дата приемки: 03 ноября 2016 Дата онлайн публикации: 06 марта 2017

Дата публикации: 27 июня 2017

Ключевые слова: послеродовый период, дисфункция щитовидной железы, факторы риска, тиреоидный аутоиммунитет

Образец цитирования: Nonchev BI, Argatska AV, Pehlivanov BK, Orbetzova MM. Risk factors for postpartum thyroid dysfunction in euthyroid women prior to pregnancy.

Folia Medica 2017;59(2):190-196. doi: 10.1515/folmed-2017-0027
Введение: Дисфункция щитовидной железы часто проявляется во время послеродового периода, а предрасполагающие факторы для её развития принято считать специфическими для исследуемого населения. Целью настоящего исследования является оценка факторов риска для появления послеродовой дисфункции щитовидной железы (ПдщЖ) среди женщин с эутиреоидным состоянием до наступления беременности.

Материалы и методы: 45 женщин с ПДщЖ и 55 эутиреоидных женщин примерно одинакового возраста после родов из города Пловдива, Болгария были включены в исследование. TSH, FT4, FT3, TPOAb, TgAb, TRAb были измерены и было проведено ультразвуковое исследование щитовидной железы во время первого триместра беременности и во время послеродового периода.

Результаты: Анализ установил более высокую степень риска развития ПДЩЖ среди женщин с фамильным анамнезом заболевания щитовидной железы (OR 4.42; 95\% Cl 1.87,10.43), курящих (OR 4.01; 95\% Cl 1.72,9.35), с персональным анамнезом аутоиммунного заболевания щитовидной железы (OR 5.37; 95\% Cl 1.15,28.53), положительным TPOAb (OR 18.12; 95\% Cl 4.93,66.65) и гипоэхогенностью щитовидной железы при УЗ во время ранней беременности (OR 6.39; 95\% Cl 2.53,16.12) и среди нуждающихся в левотироксине во время беременности (OR 3.69; 95\% Cl 1.28,10.61). ИТМ до наступления беременности был значительно более низким среди женщин с ПДЩЖ по сравне-

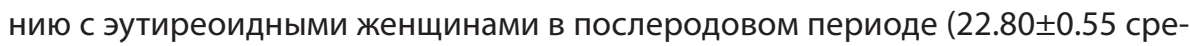
щу 26.25 $\pm 0.97, \mathrm{p}=0.013)$. Многофакторный анализ логистической регрессиии идентифицирует в качестве важнейших независимых факторов риска появления ПДЩЖ наличие положительных ТРОАЬ во время ранней беременности, фамильный анамнез заболеваний щитовидной железы, курение и низкий ИТМ до наступления беременности.

Заключение: Наши результаты устанавливают, что несколько факторов можно связывать с повышенным риском наступления ПДЩЖ среди исследованного населения и скрининг заболеваний щитовидной железы среди данной группы женщин может быть весьма полезным. 